\title{
A Human Rights Approach to the Labor Rights of Undocumented Workers
}

\author{
It's no fun being an illegal alien.
}

-Genesis, "Illegal Alien"

Between two and three million undocumented aliens currently hold full-time jobs in tlie United States. ${ }^{1}$ These persons have sought employment in tlie U.S. economy due to hardship in their countries of origin and prospects of better economic opportumity in America. $^{2}$ They are disproportionately paid substandard wages, ${ }^{3}$ penalized for participating in union activities, ${ }^{4}$ and subjected to abysmal working-place environinents. ${ }^{5}$ Yet despite the many imstances of grave exploitation, our nation "refuses to provide [to undocumented workers] the social services or legal protec-

1. Corwin, The Numbers Game: Estimates of Illegal Aliens in the U.S. I970-1981, 45 LAW \& CONTEMP. ProBs. 223, 248-49 \& n.85 (1982).

2. Peterson v. Neme, 222 Va. 477, 482, 281 S.E.2d 869, 871 (1981). This Comment suggests that the U.S. policy of criminalizing the immigration of undocumented workers is a poor solution to the conditions that cause and result from illegal immigration, and that the policy should be reassessed. At least until recently, despite anti-immigration statutes and rhetoric, the U.S. has operated a "half-open door" at the borders, tacitly encouraging the influx of cheap labor. See Developments in the Law-Immigration Policy and the Rights of Aliens, 96 HARV. L. REV. 1286, 1453 \& n.106 (1983). On the other hand, aliens, such as the Chinese railroad workers, built much of our nation's economic foundation. See Hull, Undocumented Alien Children and Free Public Education: An Analysis of Plyler v. Doe, 44 U. PITT. L. REV. 409, 410 (1983).

The Immigration Reform and Control (Simpson-Rodino) Act of 1986, Pub. L. No. 99-603, 1986 U.S. CODE CoNG. \& ADMIN. NEws (100 Stat.) [hereinafter Simpson-Rodimo Act], changes at least the government's rhetoric, by calling for the imposition of sanctions against certain employers of undocumented aliens, id., tit. I, sec. 101, § 274A, and pronouncing "the sense of the Congress that ... the immigration laws of the United States should be enforced vigorously and uniformly. . . ." Id., sec. 115.

The impact the Simpson-Rodino Act will have on the flow of illegal immigrants is far from selfevident. Compare Applebome, Border People Doubt Bill Will Slow Alien Flow, N.Y. Times, Oct. 29, 1986, § 1, at Al, col. 4 (nat'l ed.) (indicating skepticism that new law will reduce illegal immigration) with Stockton, Mexicans Expecting No Good of Immigration Law, N.Y. Times, Nov. 6, $1986, \S 1$, at A12, col. 2 (nat'l ed.) (noting that new law could "dry up the sources" of employment that prompt illegal immigration).

3. "Almost $24 \%$ [of illegals] were paid less than the minimum wage, compared to $6.2 \%$ of American workers" during a monitored period. Kutchins \& Tweedy, No Two Ways About It: Employer Sanctions Versus Labor Law Protections for Undocumented Workers, 5 INDUS. REL. L.J. 339,344 (1983).

4. See, e.g., Sure-Tan, Inc. v. NLRB, 467 U.S. 883, 886-87 (1984); Local 512, Warehouse \& Office Workers' Union v. NLRB, 795 F.2d 705, 709 (9th Cir. 1986); NLRB v. Apollo Tire, 604 F.2d 1180, 118I-82 (9th Cir. 1979).

5. Carillo v. Ballin, Civ. No. 82650 (Super. Ct., Monterey County, Calif. filed Sept. 23, 1985). 
tions available to other members of society." 6

The Umited Nations has recognized the deprivations that migrant workers endure and has addressed the issue in terms of international human rights law. ${ }^{7}$ Given the widespread presence of undocumented workers in the Uinited States and the inevitability of such migration in the face of a world economic order of massive inequality, our nation should similarly protect their huinan rights. ${ }^{8}$

This Comment discusses legal theories under which undocuinented workers can secure labor-related human rights protection. Possible domestic law sources are exainined first. Next, the Comment explores the principles of international human rights law contained in both treaty and custom as sources of remedies. Finally, the Coinment suggests synthesizing domestic and international law, drawing principles from the international law of human rights to infuse the many open-ended provisions and doctrimes of domestic law with positive ineaning.

I

\section{DOMESTIC LAW}

Direct application of doinestic law turns largely on the issue of whether undocumented workers may invoke statutes and the Constitution in domestic fora. Courts accept as "obvious that undocumented aliens possess basic constitutional rights."9 Unfortunately, there is little

6. Developments, supra note 2, at 1437-38. Where, for example, is the remedy for the legal representatives of someone such as migrant worker Juan Chabolla Casillas, whose body was dumped over the Mexican border after he died from working near dangerous pesticides? See Letter from Cesar Chavez, United Farm Workers (undated) (on file with author); see also Pesticide Link Investigated in Farm Worker Death, San Jose Mercury News, Aug. 12, 1985, at 8B, col. 4.

7. See, eg., U.N. Doc. E/CN.4/Sub.2/1985/4, at 5 (May 29, 1985); G.A. Res. 172, 34 U.N. GAOR Supp. (No. 46) at 188 (1979); U.N. Doc. A/34/46 (1980); U.N. Doc. E/CN.4/1325 (Oct. 23, 1978).

8. See Mosk, Address, United States Involvement in International Human Rights: An Overview, 7 WHITTIER L. REV. 663, 665 (1985) (basic requirements should be assured "everyone" in "land of plenty"); Schneebaum, Human Rights in the Federal Courts: A Review of Recent Cases, 44 U. PITT. L. REV. 287, 295 (1983) (optimism warranted regarding aliens' legal rights); Developments, supra note 2, at 1433-44 (United States cannot blithely ignore rights of illegal aliens).

9. Schneebaum, supra note 8, at 293 (citing Orantes v. Smith, 541 F. Supp. 351 (C.D. Cal. 1982)); see also Plyler v. Doe, 457 U.S. 202, 210 (1982) ("aliens whose presence in this country is unlawful, have long been recognized as 'persons' guaranteed due process of law"). As far back as 1886, the Supreme Court recognized that the Consititution guaranteed certain rights to any person within the borders of the United States, even illegally. Yick Wo v. Hopkins, 118 U.S. 356, 368-69 (1886). While the privileges and immunities clause applies only to "citizens," the due process and equal protection clauses apply to all persons. U.S. CoNST. amend. XIV, § I. For a recent lower court opinion upholding this principle, see Medina v. O'Neill, 589 F. Supp. 1028, 1033 (S.D. Tex. 1984).

Undocumented status does not deprive a person of labor-related rights. Local 512, Warehouse \& Office Workers' Union v. NLRB, 795 F.2d 705, 718 n.12 (9th Cir. 1986) (listing cases where undocumented workers had been allowed to collect back pay); see also Note, Illegal Aliens as "Employees" Under The National Labor Relations Act, 68 GEO. L.J. 851, 865 \& n.84 (1980) 
case law dehneating the scope of their rights. This paucity of precedent stems from the hesitancy of undocumented workers to file lawsuits that might draw attention to their immigration status. ${ }^{10}$ Nevertheless, there are constitutional principles and statutory provisions that should protect the labor rights of illegal ahens. This Part will discuss theories based on constitutional equal protection and due process analysis and statutes such as the Fair Labor Standards Act $^{11}$ and the National Labor Relations Act. ${ }^{12}$

\section{A. Constitutional Law}

Undocumented ahiens, as "persons" within the meaning of the Constitution, may turn to that document to secure pubhic education for their children, ${ }^{13}$ to protect themselves from improper deportation or exclusion, ${ }^{14}$ and to protect themselves from arbitrary detention. ${ }^{15}$ Equal protection doctrine suggests that classifications that burden undocumented workers should receive enhanced judicial scrutiny, and due process notions guarantee fundamental rights to all whom the Constitution counts as "persons." In addition, the ninth amendinent may aid the phight of undocumented workers.

\section{Equal Protection}

In a leading case on the rights of illegal aliens, Plyler v. Doe, ${ }^{16}$ the Supreme Court held that a Texas law which demed children of illegal

(violation of immigration laws does not negate all rights). An illegal alien can, for example, bring suit on an employment contract. Nizamuddowlah v. Bengal Cabaret, Inc., 69 A.D.2d 875, 415 N.Y.S.2d 685, motion for leave to appeal dismissed, 48 N.Y.2d 609, 400 N.E.2d 372, 424 N.Y.S.2d 1026 (1979).

10. See Developments, supra note 2, at 1434; see also Hull, supra note 2, at 410-11 ("Given their clandestine existence, undocumented aliens have been understandably reluctant to assert their interests in court.") (footnote omitted).

Well aware of their employees' risky position, employers may take advantage by paying substandard wages. If undocumented workers complain, employers can remedy the problem by a quick telephone call to the Immigration and Naturalization Service (INS). Ortega, Plight of the Mexican Wetback, 58 A.B.A. J. 251, 251-52 (1972). Although the Supreme Court in Sure-Tan held that reporting undocumented workers to the INS in retaliation for complaints about labor rights now amounts to an unfair labor practice, undocumented workers still face formidable obstacles in directly invoking domestic law. See Sure-Tan, Inc. v. NLRB, 467 U.S. 883, 895-96 (1984) (construing $\S 8(a)(3)$ of the National Labor Relations Act, 29 U.S.C. $\S 158$ (1982)).

For discussion of the Sure-Tan decision, see Kutchins \& Tweedy, supra note 3, at 355; Recent Developments, Illegal Aliens' Rights Under the NLRA, 1983 W1S. L. REV. 1525, 1526; infra notes 49-51 and accompanying text.

11. 29 U.S.C. $\$ \S 201-219$ (1982).

12. 29 U.S.C. $\$ \S 151-169$ (1982).

13. Plyler v. Doe, 457 U.S. 202, 210 (1982).

14. Augustin v. Sava, 735 F.2d 32, 37 (2d Cir. 1984).

15. See Jean v. Nelson, 105 S. Ct. 2992, 3005 (1985) (Marshall, J., dissenting).

16. 457 U.S. 202 (1982). 
aliens access to free public education violated the equal protection clause of the fourteenth amendment. ${ }^{17}$ Although declining to accord illegal aliens the level of judicial solicitude accorded racial minorities, the Court nevertheless recognized that classification as an "alien" could be both sufficiently suspect and burdensome as to require special judicial scrutiny. ${ }^{18}$ The Court thus "flatly rejected Texas' claim that the equal protection of the laws does not extend to undocumented aliens,"19 and deemed this class of persons "within the pale" of equal protection. ${ }^{20}$ However, the Court meant only that their equal protection interests could not be ignored, not that those interests could not be overridden.

In one respect, the Plyler case was easy. The case involved sympathetic plaintiffs, children, who did not willfully break the law. ${ }^{21}$ Courts are less likely to be sympathetic in a case involving the labor rights of undocumented aliens who are "voluntary" lawbreakers. In such a case, courts might be more likely to find that the government's interest in controlling immigration overrides the undocumented workers' equal protection rights.

Undocuinented workers' migratory habits are not, however, purely a function of choice-many cross Umited States borders of necessity. ${ }^{22}$ In view of the large number of illegal aliens in this country and the squalid conditions they endure, their presence cannot be passed off simply as "voluntary." Decisions to migrate result from highly coercive political, social, and economic forces. Courts must directly address these harsh facts before pronouncing undocumented workers "criminals," whose interests warrant hittle consideration under the equal protection clause. Undocumented workers are better characterized as econoinic refugees, rather than opportunists. ${ }^{23}$ Although the United States does not bear the responsibility of financially supporting the world's poor, undocumented aliens deserve full equal protection rights by virtue of their peculiar position in the American economy. ${ }^{24}$

17. Id. at $217-30$.

18. Id. at 223-24. For amplification of this point, see Hull, supra note 2, at 419 n.49.

19. Perry, Equal Protection, Judicial Activism and the Intellectual Agenda of Constitutional Theory: Reflections on, and Beyond, Plyler v. Doe, 44 U. PITT. L. REV. 329, 331 (1983).

20. See Lichtenberg, Within the Pale: Aliens, Illegal Aliens and Equal Protection, 44 U. P1TT.

L. REV. 351, 374-75 (1983).

21. Plyler, 457 U.S. at 207; see also Lichtenberg, supra note 20, at 374-75.

22. Ortega, supra note 10 , at 253.

23. The latter term more aptly describes their employers. See Developments, supra note 2, at 1437.

24. Undocumented workers are integral to the United States' economy and community. See infra text accompanying notes 198-202. And, in light of the "uncontroverted history of their abuse and exploitation," Doe v. Plyler, 458 F. Supp. 569, 583 (1978), aff'd, 457 U.S. 202 (1982), undocumented workers deserve sympathy in their own right. But see Plyler, 457 U.S. at 219 ("Persuasive arguments support the view that a State may withhold its beneficence from those whose very presence within the United States is the product of their own unlawful conduct."). 
The Plyler Court intimated that denial of employment rights might further Texas' and Congress' putative goal of reducing illegal immigration. ${ }^{25}$ But even at the lowest level of equal protection analysis the government must have a legitimate interest that a regulatory classification purports to further. ${ }^{26}$ Denying equal enforcement does not significantly advance the governmental interests, ${ }^{27}$ because denyimg einployinent rights will not necessarily stem the tide of illegal immigration. ${ }^{28}$ In the first place, undocumented workers are excluded from the United States based on their immigration status, not their employment status. ${ }^{29}$ Further, until recently, the "Texas Proviso" of the Immigration and Nationality Act also cut agamst linking demal of einployment rights to reduction of illegal immigration because it expressly excluded employment from the list of outlawed activities whicl constituted "harboring" illegal ahiens. ${ }^{30}$

Secondly, empirical data, though less than conclusive, undermine any such link. In spite of current deprivations of employment rights, illegal immigration contimues to increase. ${ }^{31}$ Logic further suggests that denial of rights merely encourages employers to exploit this cleap work force, whereas enforcement might lead employers to hire citizens or legal aliens. Employers would no longer have an economic incentive to hire undocumented aliens.

\section{Due Process}

Due process suggests additional theories of protection. First, due process applies to people within the jurisdiction of the Umited States, whether or not they are present legally. "Person," then, within the meaning of the due process clauses of the fifth and fourteenth annendments, "is broad enougli to include any and every liuman being." 32

25. Plyler, 457 U.S. at 210.

26. E.g., New Orleans v. Dukes, 427 U.S. 297, 303 (1976) (per curiam); Railway Express Agency v. New York, 336 U.S. 106, 110 (1949).

27. See infra notes 190-95 and accompanying text.

28. See Hull, supra note 2, at 410 . Equal protection doctrine always requires that the chosen classification rationally relate to the proffered objective. See, e.g., Plyler, 457 U.S. at 216-19.

29. See Plyler, 458 F. Supp. at 583, aff'd, 457 U.S. 202.

30. See 8 U.S.C. $\$ 1324$ (a) (1976), repealed by Simpson-Rodino Act, supra note 2; see also Hull, supra note 2 , at 425 n. 70 .

31. For a discussion debunking the proposition that failure to enforce employment rights would discourage illegal immigration to seek employment, see Peterson v. Neme, 222 Va. 477, 482, 281 S.E.2d 869, 871-72 (1981); see also Ortega, supra note 10, at 253 (sustenance requirements outweigh fear of exploitation).

32. Wong Wing v. United States, 163 U.S. 228, 242 (1896) (Field, J., concurring); see also Haitian Refugee Center v. Civiletti, 503 F. Supp. 442, 454 (S.D. Fla. 1980) (due process protects aliens within United States' borders); Note, supra note 9, at $860 \mathrm{n} .56$ (illegal aliens can claim due process protections); Developments, supra note 2, at 1445 (illegal aliens are within group protected by due process). 
The due process-based notion of fundamental fairness should therefore guarantee the rights of undocumented workers. However, such is not always the case. Lax enforcement of immigration laws suggests a thinly veiled policy of encouraging illegal immigration. ${ }^{33}$ The United States uses illegal alien labor to "produce its food and goods more cheaply."34 Yet United States law does not protect undocumented workers' human rights. ${ }^{35}$ Our government has accepted the benefits of cheap labor, by allowimg illegal immigration, but has not accepted responsibility for those laborers' rights. This type of selective application of law offends due process because it seems fundamentally unfair.

Recognizing undocumented ahens as persons should also mean that they retam the full panoply of constitutional procedural safeguards. For example, undocumented aliens should not be compelled, outside the immigration process itself, to testify to their alienage, even where they are economic, as opposed to political, refugees. ${ }^{36}$

In the context of substantive rights, courts appear more ready to scrutinize deprivations endured by undocumented workers when the deprivations affect fundamental rights. ${ }^{37}$ This development suggests that courts are employing a slidimg scale whereby discrimination against illegal aliens becomes less acceptable as the right involved becomes more fundamental.

The case of employment rights of undocumented workers, like the educational rights of their children, highlights the madequacy of rigid levels of scrutiny in either the due process or the equal protection context. In Plyler, the Court rejected arguments that education is a fundamental right, ${ }^{38}$ and was unwilling to desiguate illegal aliens a suspect class. ${ }^{39}$ Nonetheless, the Court recognized education as an important right, and the burdened class as discrete and insular, which triggered somewhat heightened judicial scrutiny of Texas' interference with the enjoyment of the right. Similarly, the Court may find that employinent rights are not "fundamental" in the due process sense. But when

33. See, e.g., Hull, supra note 2, at 410; Developments, supra note 2, at 1453.

34. Developments, supra note 2, at 1437-38.

35. Even the Simpson-Rodino Act, supra note 2, which purports to comprehensively reform United States immigration standards, declines to safeguard the human rights of aliens. But cf. id., tit. VI, sec. 601 (establishing commission to study and propose solutions for causes of illegal immigration).

36. Haitian Refugee Center, 503 F. Supp. at 513; cf. Local 512, Warehouse \& Office Workers' Union v. NLRB, 795 F.2d 705, 710 (9th Cir. 1986) (undocumented workers permitted to testify under assumed names and to refuse to answer questions about immigration status). However, some courts contend that aliens, even those lawfully present, do not enjoy many constitutional protections in the context of INS proceedings. E.g., Lopez v. INS, 758 F.2d 1390, 1393 (10th Cir. 1985).

37. Developments, supra note 2, at 1445.

38. Plyler, 457 U.S. at 223 ("[n]or is education a fundamental right").

39. Id. 
employment rights are demed to a class deserving special solicitude, sucl1 as undocumented workers, courts should follow Plyler in requiring a strong and related governmental interest before allowing a deprivation.

While the Supreme Court lias yet to characterize employinent rights in terins of due process, it lias deemed the pursuit of a coininon calling a "basic and essential activity" in a series of cases resting on the privileges and immunities clause. ${ }^{40}$ Althougli doctrinal ortlodoxy may not support wholesale importation of this theory into the law of due process, the "fundamentalness" of the right to earn a living retains independent vitality. ${ }^{41}$ Applying the slidimg scale, which balances the right's importance against the degree of pernissible discrimination, would require court enforcement of the employinent riglits of undocuinented aliens.

In addition to the uncertain impact it lias on the pace of illegal immigration, ${ }^{42}$ declining to enforce einployment rights fosters the creation of an underclass, ${ }^{43}$ which renders undocumented aliens and their cliildren a further burden on society. Therefore, this country would serve its own best interest by protectimg undocumented workers' einployment-related riglits.

\section{B. Statutory Law}

Undocumented workers may also turn to statutory law for assistance. Statutory law concerning einployment riglits falls into two general categories. The first consists of standards for wages, lours, working conditions, and the like, as set forth in the Fair Labor Standards Act (FLSA) ${ }^{44}$ The second category consists of organizational rules-rights and duties concerning relationships between organized labor and man-

40. E.g., Supreme Court of New Hampshire v. Piper, 105 S. Ct. 1272, 1277 n.9 (1985); United Bldg. \& Constr. Trades Council v. Camden, 465 U.S. 208, 219 (1984).

41. Truax v. Raich, 239 U.S. 33, 41 (1915).

42. See supra note 2 and accompanymg text.

43. See Kutchins \& Tweedy, supra note 3, at 370; Developments, supra note 2, at 1434.

44. 29 U.S.C. $\$ \S 201-219$ (1982). Many states have analogous statutes. E.g., AlASKa STAT. $\S \S 23.10 .050-150$ (1984); ARK. STAT. ANN. $\S \S 81-318$ to -332 (1976); CoNN. GEN. STAT. $§ \S 31-58$ to -76K (1972); DEL. CoDE ANN. tit. 19, §§ 901-914 (1985); GA. CoDE ANN. §§ 34-4-2 to -6 (1981); HAw. REV. STAT. §§ 387-1 to -15 (1986); IDAHo CODE $\S \S 44-1501$ to -1509 (1977); KY. REV. STAT. ANN. \$§ 337.010-.993 (Michie 1983); ME. REV. STAT. ANN. tit. 26, §§ 661-672 (1978); MD. ANN. CoDE art. 100, §§ 81-93 (1979); MASS. GEN. LAWS ANN. ch. 151, §§ 1-22 (1982); MiNN. STAT. chs. 177.21-.376 (1966); MoNT. Code ANN. $\$ \S 39-3-401$ to -408 (1985); NEB. REv. Stat. $\S \S 48-1201$ to -1209 (1984); N.H. REV. STAT. ANN. $\S \S 279: 1-: 29$ (1977); N.M. STAT. ANN. $\S ~ 50-4-$ 19 to -30 (1978); N.C. GeN. STAT. \$§ 95-25.1-.25 (1985); N.D. CENT. CodE $\$ \S 34-06-01$ to -20 (1980); OHIo REv. CoDE ANN. $\$ \S 4111.01-.99$ (Anderson 1977); OR. REv. STAT. $\$ \S 653.010-$ 654.991 (1985); R.I. GEN. LAws $\S \S 28-12-1$ to -24 (1979); S.D. CoDIFIED LAws $\$ \S 60-11-1$ to -23 (1978); TeX. Rev. Civ. STat. ANN. art. 5159d (Vernon 1971); VT. STat. ANN. tit. 21, §§ 381-396 (1978); VA. Code ANN. $\S \S 40.1-28.8$ to -28.12 (1986); WASH. REV. Code ANN. $\$ \S 49.46 .005-120$ (1962 \& Supp. 1985); W. VA. CodE $\S \S ~ 21-5 C-1$ to -11 (1985); WIS. STAT. §§ 104.01-.12 (1973); WYo. STAT. $\$ \$ 27-4-201$ to -204 (1983). 
agement-as prescribed by the National Labor Relations Act (NLRA). ${ }^{45}$

In both categories, courts have defined "employee" to include undocumented workers. ${ }^{46}$ A New York appellate court allowed an undocumented worker from Mexico to recover, under the FLSA, underpaid and unpaid wages for work as a domestic service employee. ${ }^{47}$ The court rejected outright an affirmative defense that illegal aliens cannot sue under the FLSA, finding that the FLSA's failure to expressly exclude illegal aliens means that their status "does not preclude [them] from recovering under the statute." 48

Despite this potential protection, an undocumented worker who pursues such an action may ultimately face deportation. ${ }^{49}$ To mitigate this risk, the Supreme Court held in Sure-Tan, Inc. v. NLRB ${ }^{50}$ that alerting immigration officials to the presence of illegal aliens in retaliation for their exercise of labor rights is illegal under the NLRA. ${ }^{51}$ Although the Sure-Tan Court held that NLRA protections apply to undocumented workers, ${ }^{52}$ the Court declined to award a backpay remedy because the undocumented workers were "unavailable for work" and because backpay could not be precisely calculated. ${ }^{53}$ The Ninth Circuit has interpreted Sure-Tan as precluding backpay only when the aggrieved undocumented workers have left the United States. ${ }^{54}$ As the law now stands, though they niay not claim full coverage of United States labor laws,

45. 29 U.S.C. $\S \S 151-169$ (1982). Many states have analogous statutes. E.g., CoLo. REv. STAT. $\S \S 8-3-101$ to -123 (1973 \& Supp. 1985); ConN. GeN. STAT. $§ \S 31-101$ to -111 (1972); Haw. REV. STAT. $\S \S 377-1$ to -18 (1986); KAN. STAT. ANN. §§ 44-801 to -831 (1981); MasS. Gen. LawS ANN. ch. 23, §§ 9O-9R (1981); MiNN. STAT. ch. 179 (1966); N.D. CENT. CODE §§ 34-12-01 to -14 (1980); OR. Rev. Stat. $\S \S 663.005-.295$ (1985); PA. STAT. ANN. tit. 43, $\S \S 211.1-13$ (Purdon 1964); R.I. GEN. LAwS \$§ 28-7-1 to -47 (1979); UTAH CODE ANN. §§ 34-20-1 to -13 (1974); VT. STAT. ANN. tit. 21, §§ 1501-1623 (1978); W. VA. CODE §§ 21-1A-1 to-1B-3 (1985); WIs. STAT. §§ 111.01.19 (1973).

46. See, e.g., Alvarez v. Sanchez, 105 A.D.2d 1114, 1115, 482 N.Y.S.2d 184, 185 (1984) (memorandum opinion) (FLSA); Sure-Tan, Inc. v. NLRB, 467 U.S. 883 (1984) (NLRA); Local 512, Warehouse \& Office Workers' Union v. NLRB, 795 F.2d 705 (9th Cir. 1986) (NLRA).

47. Alvarez, 105 A.D.2d 1114, 482 N.Y.S.2d 184.

48. Id. at 1115,482 N.Y.S.2d at 185 (citations omitted).

49. See supra note 10 and accompanying text.

50. 467 U.S. 883 (1984).

51. Id.; see also Note, Striking a Balance Among Illegal Aliens, the INA, and the NLRA: SureTan v. NLRB, 12 Pepperdine L. Rev. 679, 688 (1985) (describing Sure-Tan as holding that alerting immigration officials constituted proscribed constructive discharge for union activity).

52. Sure-Tan, 467 U.S. at 891-94. A unit of employees composed mostly of illegal aliens selected a union as their collective bargaining representative pursuant to National Labor Relations Board (NLRB) procedures. The employer filed objections with the NLRB on the sole basis of the employees' immigration status, and sent a letter to the Immigration and Naturalization Service, resulting in the employees' prompt "voluntary" departure for Mexico. Id. at 887.

53. Id. at 899-905.

54. Local 512, Warehouse \& Office Workers' Union v. NLRB, 795 F.2d 705, 722 (9th Cir. 1986). In contrast to Sure-Tan, the undocumented workers in this case remained in the country, and their backpay was precisely calculable. $I d$. at 717 . 
"workers who lack papers may nevertheless form and join unions, elect bargaining representatives, and enforce minimunı wage, hour, and occupational safety and health statutes."55

Sound pohicy, as well as the constitutional arguinents addressed previously, suggest that any limits that remain on statutory protections should be totally removed. Failing to do so encourages employers to hire undocuinented aliens at substandard wages and in derogation of their organizational rights, thereby undercutting the domestic labor market and flouting immigration laws. ${ }^{56}$ Aliens will immigrate as long as this country offers greater opportunities than the countries they leave behind. ${ }^{57}$ Enforcing statutory rights would bring these workers into parity with domestic workers, support NLRA and FLSA pohicies, and quell the cries of those who complain that undocumented workers displace doniestic workers by accepting eniployment in substandard conditions. ${ }^{58}$

Domestic statutory law thus provides legal handholds for undocumented workers, but is both limited in scope by statutory construction and subject to change in response to political trends. ${ }^{59}$ Consequently, while continuing to pursue domestic law rehef, an undocumented worker litigant would be well-advised also to pursue rehef through international law.

II

\section{INTERNATIONAL LAW}

International law, if capable of apphication and invocation in the United States, can protect the rights of undocumented workers. International law includes pronouncements that concern the rights of all human beings and guarantee the right to work, fair wages, safe working conditions, reasonable hours, and the right to organize and bargain collectively. ${ }^{60}$ Declarations announced by international organizations such as

55. Kutchins \& Tweedy, supra note 3 , at 341 (footnote omitted).

56. See Local 512, 795 F.2d at 719. For thorough discussions of this rationale, see, e.g., Kutchins \& Tweedy, supra note 3, at 370, and Recent Decision, Labor Law-Illegal Aliens: NLRB v. Apollo Tire, 16 Gonz. L. Rev. 201, 209-10 (1980).

57. See supra notes 2 and 22 and accompanying text.

58. See Local 512, 795 F.2d at 719; Note, supra note 51, at 687; Kutchins \& Tweedy, supra note 3 , at 370 .

59. For example, the Simpson-Rodino Act, supra note 2, which imposes sanctions on employers who hire illegal aliens, $i d$., tit. I, sec. 101, $\S 274 \mathrm{~A}(\mathrm{e})(4)(\mathrm{A})$, precludes undocumented workers from openly advocating for employment rights and fair labor standards for undocumented workers.

60. See, e.g., U.N. Charter art. 55, para. (a); American Convention on Human Rights, done Nov. 22, 1969, O.A.S.T.S. No. 36, at 1, Off. Rec. OEA/Ser.L/V/II.23, doc. 21, rev. 6, art. 16 (entered into force July 18, 1978) [hereinafter American Convention]; International Covenant on Civil and Political Rights, adopted Dec. 16, 1966, G.A. Res. 2200, 21 U.N. GAOR Supp. (No. 16) at 52, U.N. Doc. A/6316 (1967), art. 22 (entered into force Mar. 23, 1976) [hereinafter Civil and Political Covenant]; International Covenant on Economic, Social and Cultural Rights, adopted Dec. 
the United Nations and the Organization of American States, the language of the instruments seeking to effectuate the general pronouncements, judicial opinions from international and doniestic tribunals, and writmgs by scholars in international and human rights law, all explicate global human rights.

This Part will explain why and how international law protects the einployinent rights of undocuniented workers. First, it will discuss the inechanics of international law, addressing treaty law and customary law, then consider how international law principles evolve from the status of aspiration, to emerging norm, and finally to binding norm. This Part will also assert the enforceability of emerging safeguards for the eniployinent rights of undocuniented workers, either by treaty, custom, or both.

\section{A. The Mechanics of International Law}

International human rights law may be invoked either as treaty law or as custoniary international law. Directly invocable treaty law consists of instruments that are sigued, ratified, and self-executing. Custoniary international law, in contrast, consists of principles, whether or not recited in writings, that constrain the actions of civilized nations. ${ }^{61}$

\section{Treaty Law and the Question of Self-Execution}

Any treaty that the United States has sigued and ratified beconies the law of the land by virtue of the supremacy clause. ${ }^{62}$ However, a

16, 1966, G.A. Res. 2200, 21 U.N. GAOR Supp. (No. 16) at 49, U.N. Doc. A/6316 (1967), arts. 6-8 (entered into force Jan. 3, 1976) [hereinafter Economic, Social and Cultural Covenant]; European Social Charter, done Oct. 18, 1961, 529 U.N.T.S. 89 (No. 7659), part I, II 1-6, part II, arts. 1-6 (entered into force Feb. 26, 1965) [hereinafter European Social Charter]; European Convention for the Protection of Human Rights and Fundamental Freedoms, signed Nov. 4, 1950, 213 U.N.T.S. 221, Europ. T.S. No. 5 (1950-52), 1953 Gr. Brit. T.S. No. 61 (Cmd. 8969), art. 11 (entered into force Sept. 3, 1953) [hereinafter European Convention]; Universal Declaration of Human Rights, signed Dec. 10, 1948, G.A. Res. 217A, U.N. Doc. A/810, at 71 (1948), arts. 23, 24 [hereinafter UDHR]; American Declaration of the Rights and Duties of Man, signed May 2, 1948, O.A.S. Off. Rec. OEA/ Ser.L/V/II.23, doc. 21, rev. 6, arts. XIV, XV, XVIII, XXII (adopted by the Ninth International Conference of American States, Mar. 30-May 2, 1948) [hereinafter American Declaration].

61. Fernandez v. Wilkinson, 505 F. Supp. 787, 796 (D. Kan. 1980), aff'd on other grounds sub nom. Rodriguez-Fernandez v. Wilkinson, 654 F.2d 1382 (10th Cir. 1981). Thus, "[w] hen most nations of the world accept a certain standard of conduct, that standard is then recognized as a norm of international law which must be followed by every civilized nation, regardless of whether there is any express international document, such as a treaty, specifically setting out the standard." Bazyler, Litigating The International Law of Human Rights: $A$ "How To" Approach, 7 WHITTIER L. REV. 713, 719 (1985).

62. U.S. CoNST. art. VI, cl. 2 ("all Treaties made, or which shall be made, under the Authority of the United States, shall be the supreme Law of the Land"); see also Sehneebaum, The Enforceability of Customary Norms of Public International Law, 8 BROOKLYN J. INT'L L. 289, 289 (1982) (Constitution expressly states supremacy of duly signed and ratified treaties). 
treaty must also be self-executing for an individual to use it in court. ${ }^{63}$ Despite the myriad tests proposed by courts and academics, "there is no sure inethod for determiming whether or not a treaty is self-executing." Nevertheless, treaties that purport to grant judicially manageable rights to individuals generally meet the requisite showing of specificity. ${ }^{65}$ As Professor Riesenfeld has suggested:

A treaty provision which by its terms and purpose is meant to stipulate the immediate and not merely progressive creation of rights, privileges, duties and immunities cognizable in domestic courts and is capable of being applied by the courts without further concretization is selfexecuting. 66

Thus, in order to invoke a right, a hitigant must choose provisions froin treaties that the Uirited States has signed and ratified, and subject those provisions to self-execution analysis.

\section{Customary International Law}

To be legally binding, then, a treaty must be signed, ratified, and self-executing. If any of these elements are missing, however, the treaty's provisions may yet be independently enforceable as customary international law. ${ }^{67}$ Customary international law consists of those principles that civilized nations generally accept as legally binding. In this context, formal legal mstruments illustrate the extent of worldwide acceptance for certain human rights irrespective of the specificity of the document in which they are found. The question of self-execution plays no role. Instead, the inquiry focuses on the primciple's extent of acceptance. ${ }^{68}$

63. RESTATEMENT (SECOND) OF Foreign RELATIONS LAW OF THE UNITED STATES § 141 (1965); see also Comment, Self-Executing Treaties and The Human Rights Provisions of the United Nations Charter: A Separation of Powers Problem, 25 Bufralo L. REv. 773, 773 (1976) (a treaty that is not self-executing requires legislative implementation before it controls domestic actions).

64. Comment, supra note 63, at 779 (footnote omitted).

65. See Frolova v. USSR, 761 F.2d 370, 374-75 (7th Cir. 1985); People of Saipan v. United States Dep't of Interior, 502 F.2d 90, 101 (9th Cir. 1974) (Trask, J., concurring), cert. denied, 420 U.S. 1003 (1975); Lillich, The Role of Domestic Courts in Enforcing International Human Rights Law, in Guide to International Human Rights Practice 225 (H. Hannum ed. 1984); De la Vega, Comments, Symposium on International Human Rights Law in State Courts, 18 INT'L LAW. 69, $70-72$ (1984); Hartman, Enforcement of International Human Rights Law in State and Federal Courts, 7 WhitTIER L. Rev. 741, 745 (1985); Riesenfeld, The Doctrine of Self-Executing Treaties and U.S. v. Postal: Win at Any Price?, 74 AM. J. INT'L L. 892, 898 (1980); Schlüter, The Domestic Status of the Human Rights Clauses of the United Nations Charter, 61 CALIF. L. REv. 110, 149 (1973); Schneebaum, supra note 62, at 293-99; Note, The Domestic Application of International Human Rights Law: Evolving the Species, 5 Hastings INT'L \& CoMP. L. REv. 161, $191-202$ (1981); Comment, supra note 63 , at 786.

66. Riesenfeld, supra note 65 , at $900-01$ (footnote omitted).

67. See Lillich, supra note 65, at 233; Schneebaum, supra note 62, at 297.

68. For example, in Filartiga v. Peña-Irala, 630 F.2d 876 (2d Cir. 1980), the Second Circuit recognized the condemnation of torture as sufficiently widespread for acceptance as a binding norm of international law. Id. at 878 . 
Therefore, customary international law provides an independent basis for the enforcement of human rights. Courts agree that "[i]t is well established that customary international law is part of the law of the Umited States,"69 and that it "must be ascertained and administered by the courts of justice ... as often as questions of right depending upon it are duly presented for their determination." 70 The undocumented worker litigant should therefore select those principles that have been sufficiently accepted so as to establish their position as binding norms of customary international law. In short, the litigant must show that the civilized nations of the world inutually condemn the deprivations undocumented workers endure. ${ }^{71}$ Accepted sources of customary international law mclude express international agreements, judicial opinions, and writings of jurists and scholars. Also, the practices of civilized nations indicate which human rights principles qualify as binding norms. ${ }^{72}$

\section{B. The Application of International Law}

Undocumented workers are appropriate subjects for humanitarian treatment under international law, as their irregular status has allowed "host" countries to subordmate their rights where expedient. In general, the imternational community has treated illegal aliens with profound ambivalence. ${ }^{73}$ For example, the International Labour Organization has specifically restricted conventions concerning migrant workers to those lawfully in their country of einployinent. ${ }^{74}$

69. Lareau v. Manson, 507 F. Supp. 1177, 1188 n.9 (D. Conn. 1980), aff'd in part, modified and remanded in part, 651 F.2d 96 (2d Cir. 1981).

70. The Paquete Habana, 175 U.S. 677,700 (1900).

71. Fernandez v. Wilkinson, 505 F. Supp. 787, 798 (D. Kan. 1980), aff'd on other grounds sub nom. Rodriguez-Fernandez v. Wilkinson, 654 F.2d 1382 (10th Cir. 1981). In issues of mutual concern, nations concern themselves with the reactions of other nations to the issue. In issues of several concern, each nation deals with the problem independently. Thus, mutual concern implies a greater level of binding acceptance.

72. Filartiga, 630 F.2d at 880; Fernandez, 505 F. Supp. at 798; Schneebaum, supra note 8, at 291 \& n.23; Note, The Application of International Human Rights Arguments in United States Courts: Customary International Law Incorporated Into American Domestic Law, 8 BROOKLYN J. INT'L L. 207, 211 n.20 (1982).

For example, the United States District Court for the District of Kansas found a binding rule against arbitrary detention of illegal alieus by referring to the Ameriean Convention on Human Rights, reports of the International Court of Justice, the works of numerous commentators, and the practices of civilized nations. Fernandez, 505 F. Supp. 787.

73. See Hull, supra note 2, at 410 .

74. Sec, e.g., Convention concerning Migration for Employment (ILO No. 97) (revised 1949), entered into force Jan. 22, 1952, art. 11, in INTERNATIONAL LABOUR CONVENTIONS AND RECOMMENDATIONS, 1919-1981 785 (1982) (convention applies to "any person regularly admitted as a migrant for employment"); Convention concerning Migrations in Abusive Conditions and the Promotion of Equality of Opportunity and Treatment of Migrant Workers (ILO No. 143) (revised 1949), entered into force Dec. 9, 1978, art. 11, in id. at 821 (1982) (convention applies to "any person regularly admitted as a migrant worker"). 
In response to the legal uncertainty and exploitation faced by undocuniented workers, ${ }^{75}$ the United Nations established a Working Group. ${ }^{76}$ The Working Group produced a Draft International Convention on the Protection of the Rights of All Migrant Workers and their Families, ${ }^{77}$ which addresses niany of the concerns addressed by this Comment, by expressly applying the basic labor rights entbodied in such documents as the Umiversal Declaration of Human Rights ${ }^{78}$ to undocuniented workers.

However, even if the United States ratified the Draft Convention, obstacles remain in applying its solution to real-life situations. The Draft Convention's guarantees nuust still be apphied through either treaty law or principles of customary international law. This Section therefore outlines the treaty law apphicable to undocuniented workers' phight, then explores the emerging international consensus regarding such workers' hiving and employment conditions.

\section{Treaty Law-The U.N. Charter is Self-executing}

Generally, treaties that address individual rights call for hiberal construction. ${ }^{79}$ Where a human rights-related treaty or treaty provision admits more than one supportable construction, that which nore generously secures individual rights should prevail. ${ }^{80}$ Provisions that arguably protect the rights of undocumented workers should therefore be construed conclusively to do so. This liberal construction conforins with the traditional Supreme Court practice of decidimg close cases $m$ favor of individuals. ${ }^{81}$ As an expansive interpretation of hunian rights pronouncements makes it less likely that the United States will violate its treaty promises, such a posture also fosters national comphiance with international obligations. ${ }^{82}$

While the U.S. has signed and ratified few of the major human rights mstrunients, ${ }^{83}$ it has ratified the U.N. Charter. Contemporary

75. See, e.g., U.N. Doc. E/CN.4/1325 (1978).

76. See G.A. Res. $34 / 172,34$ U.N. GAOR Supp. (No. 46) at 189, U.N. Doc. A/34/46 (1980).

77. U.N. Doc. A/C.3/40/WG1/CRP/1 (1985).

78. UDHR, supra note 60 .

79. Asakura v. Seattle, 265 U.S. 332, 342 (1924).

80. See Schlüter, supra note 65 , at 148.

81. Id.; see also De la Vega, supra note 65 , at 70 (courts should construe treaties broadiy with respect to rights that may be claimed under them).

82. See Christenson, Using Human Rights Law to Inform Due Process and Equal Protection Analyses, 52 U. CIN. L. REv. 3, 34 (1983).

83. Notably, the United States has not signed and ratified the Economic, Social and Cultural Covenant, supra note 60, the Civil and Political Covenant, supra note 60, the American Convention on Human Rights, supra note 60, or the International Convention on the Elimination of All Forms of Racial Discrimination, opened for signature Mar. 7, 1966, 660 U.N.T.S. 195 [hereinafter Convention on Discrimination]. Chart of Ratifications of Major Interuational Human Rights 
scholars and this Comment assert that the Charter should be deemed self-executing at least in the context of labor standards and labor rights, ${ }^{84}$ although early cases held otherwise. ${ }^{85}$ Three dominant concerns therefore emerge. ${ }^{86}$ The first is whether the organization intended the Charter's provisions to be self-executing; ${ }^{87}$ second is whether the provisions at issue are judicially manageable-sufficiently specific and realistically implementable; and third is whether the consequences of declaring the treaty promise self-executing are acceptable to the parties to the treaty.

\section{a. Intent}

The language and context of the Charter connote obligation, particularly the so-called implementation provisions in articles 55 and 56. Article 55 includes principles of "full employment" and "universal respect for, and observance of, human rights and fundamental freedoms for all ...."88 Article 56 pledges member states to act pursuant to these principles. ${ }^{89}$ Thus, while the Charter addresses certain human rights principles as aspirations, it obliges member states to adhere to concrete norms in pursuit of these goals. Actions which interfere with members' obligations and impede the achievement of these goals contravene the Charter.

Subsequent actions by the U.N. inake clear that the Charter's parties intended some of its provisions to be self-executing. The Universal Declaration of Human Rights ${ }^{90}$ and other documents of the International Bill of Human Rights ${ }^{91}$ provide the standards of compliance. For example, specifying that "[e]veryone has the right to work, to free choice of employment, to just and favourable conditions of work and to protection agamst unemployment," ${ }^{92}$ indicates that the Charter's promotion of

Instruments as of $1 \mathrm{Jan} .1982$ in Annex 1 to UNESCO, ThE INTERNATIONAL DimENSION OF Human Rights (1982).

84. A treaty need not be self-executing in its entirety for some of its provisions to be so deemed. See Hartman, supra note 65 , at 745 ; $c f$. De la Vega, supra note 65 , at 72 (discussing self-execution of specific provisions of U.N. Charter).

85. E.g., Sei Fujii v. California, 217 P.2d 481 (1950), aff'd, 38 Cal. 2d 718, 242 P.2d 617 (1952); Sipes v. McGhee, 316 Mich. 614, 25 N.W.2d 638 (1947), rev'd. 334 U.S. 1 (1948) (as companion case to Shelley v. Kraemer, 334 U.S. 1 (1948)).

86. Comment, supra note 63 , at 779 .

87. Actual intent may prove particularly difficult to discern in the context of multilateral treaties, but interpretive tools of language construction, and resort to prior and subsequent pronouncements, facilitate this inquiry.

88. U.N. CHARTER art. 55 (a), (c).

89. Id., art. 56. The Charter does not prescribe interlocutory duties of member nations, which might preclude self-execution. That is, the Charter is binding without further action by the United States. See Schneebaum, supra note 62, at 293-96.

90. UDHR, supra note 60 .

91. Economic, Social and Cultural Covenant, supra note 60; Civil and Political Covenant, supra note 60; see also infra note 126.

92. UDHR, supra note 60 , art. 23 , para. 1 . 
full einployment einbodies concrete obligations. Tlus, the U.N. intended the Charter to create specific obligations.

\section{b. Judicial Manageability}

The Charter's guarantees of nondiscrimination and employinent rights are clear enougl for courts to understand and adjudicate rights accordingly. Courts of $\mathrm{Canada}^{93}$ and India, ${ }^{94}$ as well as federal and state courts in this country, ${ }^{95}$ have held portions of the Charter self-executing and recognized legal obhigations thereunder.

In addition, the precision of the International Bill of Human Rights contributes to judicial manageability. At least one court has held that United Nations declarations "are significant because they specify with great precision the obhigations of member nations under the Charter."96 The Universal Declaration's article 23 specifies labor standards and labor rights, ${ }^{97}$ to which "[e]veryone is entitled . . . without distimction of any kind," by virtue of article $2 .{ }^{98}$ The International Covenant on Economic, Social and Cultural Rights ${ }^{99}$ similarly guarantees the right to work, ${ }^{100}$ fair labor standards, ${ }^{101}$ and labor rights, ${ }^{102}$ whicll are also to be exercised "without discrimination of any kind."103 These agreements, promulgated by the same body that issued the Charter, provide further precision for judges to apply the Charter's human rights norms to protect the rights of individual hitigants. Thus, where an undocumented worker establishes that labor laws or labor standards have not been enforced for his or her protection, the hitigant has made out a case for a violation of article 55 of the United Nations Charter, entitling the undocumented worker to judicial recognition and relief. ${ }^{104}$

93. Re Drummond Wren, [1945] O.R. 778, 781. But cf. Re Noble and Wolf, [1948] O.R. 579, 592 (questioning application of U.N. Charter without legislative implementation).

94. 24 INDIAN L.R. 426-27 (Orissa 1957) (cited in Schlüter, supra note 65, at 125 n.185).

95. See, e.g., Keeney v. United States, 218 F.2d 843, 844-45 (D.C. Cir. 1954) (arts. 100, 105); Curran v. City of New York, 191 Misc. 229, 77 N.Y.S.2d 206 (Sup. Ct. 1947) (art. 104).

96. Filartiga v. Peña-Irala, 630 F.2d 876,883 (2d Cir. 1980).

97. UDHR, supra note 60 , art. 23; see also infra text accompanying note 118.

98. UDHR, supra note 60 , art. 2.

99. Economic, Social and Cultural Covenaut, supra note 60.

100. Id., art. 6.

101. Id., art. 7.

102. Id., art. 8.

103. Id., art. 2, para. 2.

104. The logical progression of the case would proceed as follows: Labor standards and rights are among the "human rights and fundamental freedoms" protected by article 55 of the Charter. U.N. ChARTER art. 55. Reference to the UDHR, supra note 60, and the Economic, Social and Cultural Covenant, supra note 60, places these rights within the Charter's guarantees. See supra text accompanying notes 97,98 and 103. Failure to act in accordance with these rights for undocumented aliens contravenes the guarantee of universal application of article 55, as supported by the pledge to action of article 56, and the proscriptions of discrimination in the supporting documents. U.N. 


\section{c. Consequences of Self- or Nonself-execution}

The legal and ethical consequences of declaring the employmentstandards and labor-rights provisions of the United Nations Charter selfexecuting commend such a development. Nonself-execution leaves the parties to a treaty with useless words, contrary to the principle that the words in legal documents presumptively mean what they say. ${ }^{105}$ Selfexecution avoids the problem of essentially empty treaty obligations. Thus, courts should resolve legal doubts in favor of applying the clauses of the Charter, for given the right to be free from certain conduct, logic dictates a correlative private right of action to enforce the legal right. ${ }^{106}$

The self-execution argument, however, is tempered by the political consideration that self-execution might call into immediate question the practices of many signatories to the Charter. While that might cause certain parties substantial discomfort, the offending states can hardly complain, as they are merely being held to legal obligations which they helped create by signing the treaties that pronounce their obligations.

Further, such a crystallization of the Charter leads to laudable political and jurisprudential results, for as the Charter matures through application and interpretation, further declarations clarify its meaning. These clarifications in turn give precise and far-reaching import to the Charter's terms. ${ }^{107}$

\section{Customary International Law-The Emergence of an Accepted Norm}

International law changes over time. New treaties come into force and custom evolves. ${ }^{108}$ For example, a human rights principle may initially appear in the international arena as an aspiration, perhaps expressed in a declaration from an interuational organization such as the U.N. As such, it does not yet command adherence, except insofar as

CHARTER arts. 55-56; Economic, Social and Cultural Covenant, supra note 60; UDHR, supra note 60.

105. Cf. United States v. Menasche, 348 U.S. 528, 538-39 (1955) (laws should be read in order " 'to give effect, if possible, to every clause'" (quoting Montclair v. Ramsdell, 107 U.S. 147, 152 (1882))).

106. Schneebaum, supra note 62, at 293; cf. Schlüter, supra note 65 , at 127 (courts should resolve legal doubts in favor of applying the clauses of the Charter because establishment of a treaty provision is a legal norm which gives rise to a presumption in favor of direct application in the courts). Contra Tel-Oren v. Libyan Arab Republic, 726 F.2d 774, 816-19 (D.C. Cir. 1984) (international law never implies right to sue) (Bork, J., concurring), cert. denied, $105 \mathrm{~S} . \mathrm{Ct} .1354$ (1985).

107. See supra notes 97-103 and accompanying text, discussing the International Bill of Human Rights. As with ordinary legislation, subsequent action by the promulgating body should be interpreted as ratifying or modifying previous judicial construction. In this case, the later clarifications support a broad construction of the Charter's human rights provisions.

108. S. Riesenfeld \& G. Hauck, Cases and Materials on International Law 29 (1986) (unpublished course materials) (on file with author). 
nations feel morally obligated to follow it. As nations conform their actions to the new principle, it will begin to emerge as a norin. When state practice manifestly evidences a consensus to which nation-states feel legally obligated, a binding norm exists. ${ }^{109}$ This consensus, though not articulated in treaty form, exerts equivalent legal force. ${ }^{110}$

A crystallized norn of international law that extends humaintarian employment rights to undocumented workers would therefore be enforceable in U.S. courts. Examination of traditional sources of customary imternational law reveals that labor rights are becoming increasingly well-recognized.

\section{a. Declarations of International Bodies}

United Nations declarations carry great weiglit in obliging precise adlierence by niember nations, such as the United States. ${ }^{111}$ In the landmark human rights case of Filartiga v. Peña-Irala ${ }^{112}$ the Second Circuit recognized the significance of such declarations. ${ }^{113}$ Althougli many argue that a declaration cannot be bimding in and of itself ${ }^{14}$-as would be the case with a treaty-it nonetlieless denionstrates acceptance of the rights involved. In this sense, the Universal Declaration of Human Rights $^{115}$ is the most significant articulation of human riglits norins accepted by the Umited Nations' inember states. ${ }^{116}$ In the Umversal Declaration, the General Asseinbly proclaimed that: "Everyone is entitled to the rights and freedons set forth in this declaration, without distinction of any kind." 117 The Declaration then recites a list of human rights, including, in Article 23:

1. Everyone has the right to work, to free choice of employment, to just and favourable conditions of work and to protection against unemployment.

2. Everyone, without any discrimination, has the right to equal pay for equal work.

109. Id.; Schwebel, Confrontation, Consensus and Codification in International Law, Address to the American Branch of the International Law Association (Nov. 3, 1978), reprinted in S. Riesenfeld \& G. Hauck, supra note 108, at 132, 136-37.

110. See S. Riesenfeld \& G. Hauck, supra note 108, at 28-30. When state practice follows a U.N. declaration, scholars debate whether the source of the custom inheres in the declaration or in the practice, but the binding force of the custom is beyond cavil. See Schwebel, supra note 109, reprinted in S. Riesenfeld \& G. Hauck, supra, at 137.

111. S. Riesenfeld \& G. Hauck, supra note 108, at 30; Schwebel, supra note 109 passim.

112. 630 F.2d 876 (2d Cir. 1980).

113. Id. at 883; see also Note, supra note 72, at 228 (discussing Filartiga).

114. See S. Riesenfeld \& G. Hauck, supra note 108, at 33 n.7 (recognizing dispute and citing arguments on both sides).

115. UDHR, supra note 60.

116. See Newman, Interpreting the Human Rights Clauses of the UN Charter, 5 HUM. RTS. J. 283, 288 (1972).

117. UDHR, supra note 60, art. 2. 
3. Everyone who works has the right to just and favourable remuneration ensuring for himself and his family an existence worthy of human dignity, and supplemented, if necessary, by other means of social protection.

4. Everyone has the right to form and to join trade unions for the protection of his interests. ${ }^{118}$

Thus, international legal instruments formally recognize employment rights.

\section{b. Judicial Opinions}

Neither the International Court of Justice nor any U.S. court has directly invoked the emerging labor rights to protect undocumented workers. ${ }^{119}$ However, the International Court in its famed Namibia opinion ${ }^{120}$ ruled that South Africa's presence in Namibia violated U.N. Charter provisions obliging observance of and respect for "human rights and fundainental freedoms for all without distinction as to race."121 This case provides analogous support for invoking nondiscrimination provisions to aid illegal aliens. ${ }^{122}$

\section{c. Writings of Scholars}

Scholarly writings elucidate the mearing of otherwise obtuse legal standards. Responsible scholars have pointed out that the broad, inclusive language of the Universal Declaration clearly embraces aliens as well as nationals. ${ }^{123}$ No distinction here is made between legal and illegal aliens. At least one draft declaration expressly limited its coverage to "lawful residents," although later drafts have left the question open. ${ }^{124}$ Scholarly commentaries also identify "specific" international docuinents

118. Id., art. 23. In further support, the U.N. General Assembly has addressed rights inherent in the worker-employer relationship, whose violation or even limitation "may be tantamount to a violation of the principles of the Universal Declaration of Human Rights." G.A. Res. 34/172, 34 U.N. GAOR Supp. (No. 46) at 188, U.N. Doc. A/34/829 (1979).

119. The law surrounding undocumented workers in particular, and the international law of human rights in general, is new and rapidly developing. See Note, supra note 72, at 233. Consequently, there is little hard precedent, and flexibility is called for in applying that which exists.

120. Legal Consequences for States of the Continued Presence of South Africa in Namibia (South West Africa) Notwithstanding Security Council Resolution 276 (1970), 1971 I.C.J. 16 (advisory opinion of June 21, 1971) [hereinafter Namibia Opinion].

121. Id. at 57 .

122. The U.S. itself cited the UDHR in its World Court case against Iran. Memorial of the United States (U.S. v. Iran), 1982 I.C.J. Pleadings (United States Diplomatic and Consular Staff in Tehran) 123, 182-83 \& nn.36, 42 (May 24, 1980).

123. See, e.g., R. Lillich, The human Rights of Aliens in Contemporary INTERNATIONAL LAW 42-44 (1984) (even the "plainest and simplest interpretation" of the UDHR guarantees a very far-reaching coverage).

124. Draft Declaration on the Human Rights of Individuals who are not Citizens of the Country in which they Live, U.N. Doc. A/C.3/38/11 (1983), reprinted in R. LILlıcH, supra note 123, at 131-34. 
which, though technically nonbinding on nonparties, may assist in defining and effectuating the norms and obligations of the "great" U.N. declarations, ${ }^{125}$ which in turn inform the content of customary international law. For example, commentators contend that the U.N. Cliarter's obligations must be measured by reference to the International Bill of Human Rights. ${ }^{126}$

\section{d. Nations Increasingly Recognize Employment Principles as Binding Norms}

As the preceding discussion indicates, the accepted sources of custom support accepting international labor standards and labor rights as binding domestic law. Judicial opinions, mternational and domestic, as yet offer few examples of undocumented workers invoking international employment rights, but this lack of precedent should not be dispositive. Recent decisions indicate that courts are willing to accept international human rights as binding norms. ${ }^{127}$ Therefore, domestic courts faced with previously uninvoked theories of international custom may turn to the United Nations Cliarter, the explanatory documents of the International Bill of Human Rights, and even to a clearly nonbinding instrument such as the European Convention for the Protection of Human Rights and Fundamental Freedoms, as evidence of the bimding nature of certain human rights norms. ${ }^{128}$

A sinilar canvass of important human rights instruments reveals that employment-related rights command the umversal attention of civilized nations. A nonexhaustive list includes article 55 of the U.N. Cliarter, ${ }^{129}$ article 23 of the Universal Declaration of Human Rights, ${ }^{130}$ articles 6, 7 and 8 of the International Covenant on Economic, Social and Cultural Rights, ${ }^{131}$ article 22 of the International Covenant on Civil and

125. Cf. Newman, supra note 116 , at 289 (some human rights treaties can help define norms of U.N. declarations).

126. See, e.g., id. at 285. The International Bill of Human Rights consists of the UDHR, supra note 60 , the Economic, Social and Cultural Covenant, supra note 60 , the Civil and Political Covenant, supra note 60 , and the Optional Protocol to the International Covenant on Civil and Political Rights, G.A. Res. 2200, 21 U.N. GAOR Supp. (No. 16) at 59, U.N. Doc. A/6546 (1966).

127. See, e.g., Filartiga v. Peña-Irala, 630 F.2d 876, 884, 886-87 (2d Cir. 1980) (official torture is clearly and unambiguously prohibited by the law of nations); Sterling v. Cupp, 290 Or. $611,622 \&$ n.21, 625 P.2d 123, 131 \& n.21 (1981) (U.N. declarations echo the U.S. Constitution's concern with minimizing harsh, degrading or dehumanizing treatment of prisoners); see also Note, supra note 72, at 233-35 (United States courts use international and domestic judicial decisions as evidence of human rights principles).

128. See, e.g., Filartiga, 630 F.2d at 881-84 (official torture); Sterling, 290 Or. at $622 \&$ n.21, 625 P.2d at $131 \& \mathrm{n} .21$ (unreasonable searches).

129. U.N. CHARTER art. 55 (full employment).

130. UDHR, supra note 60, art. 23 (right to work, just labor standards, trade unionization).

131. Economic, Social and Cultural Covenant, supra note 60, arts. 6, 7, 8 (right to work, labor standards, unionization). 
Political Rights, ${ }^{132}$ articles XIV and XXII of the American Declaration of the Rights and Duties of Man, ${ }^{133}$ article 16 of the American Convention on Human Rights, ${ }^{134}$ article 11 of the European Convention for the Protection of Human Rights and Fundamental Freedoms, ${ }^{135}$ and part I and articles 1 through 6 of the European Social Charter, ${ }^{136}$ which variously set forth guarantees of employment, labor standards, and trade umion rights. ${ }^{137}$

As the exploitation of undocumented workers receives more attention from the media and the legal world, heretofore dormant principles are coalescing into legal doctrine. That no one successfully sued for damages stemming from torture before Filartiga did not mean there was not a legally bimding norm condemning it. Nor did the fact that some nations contmued to engage in torture preclude a successful suit. Instead, the important factors were the widespread acceptance of an antitorture principle and the fact that even those nations that perpetrated torture publicly condemned it. ${ }^{138}$ Similarly, international human rights instruments evidence the widespread acceptance of an anti-exploitation principle, and even those nations that allow it speak out against exploitation of workers. ${ }^{139}$ Accordingly, courts should enforce employment rights as customary international law as soon as a litigant demonstrates the universality of these rights.

The writings of jurists and legal scholars further support recognizing employment rights as binding custom. For example, Justice Stanley Mosk of the Califorina Supreme Court has addressed the right to work as a "basic requirement" of international human rights law. ${ }^{140}$ Other commentators argue more expansively that the Universal Declaration of Human Rights states the concrete norms of custom in international human rights law. ${ }^{141}$

Additionally, though transnational empirical data may not address the universality of labor standards and rights, the legal instruments of

132. Civil and Political Covenant, supra note 60 , art. 22 (unionization).

133. American Declaration, supra note 60, arts. XIV, XXII (right to work, labor standards, unionization).

134. American Convention, supra note 60, art. 16 (unionization).

135. European Convention, supra note 60, art. 11 (unionization).

136. European Social Charter, supra note 60, pt. I, arts. 1-6 (right to work, labor standards, unionization).

137. The normative content of these unratified or nonself-executing documents remains independently enforceable as custom. See Schneebaum, supra note 62, at 297 (discussing U.N. Charter as custom); see also supra text accompanying notes 67-70.

138. See Filartiga, 630 F.2d at 884.

139. See Transcript of the President's Address to the General Assembly, N.Y. Times, Oct. 25, $1985, \S 1$, at 11, col. 1 (describing UDHR as "affirming flame" of United States).

140. Mosk, supra note 8, at 665 .

141. See, e.g., Bazyler, supra note 61, at 717 (UDHR has attained "treaty-like" status). 
nations throughout the world protect employment rights. ${ }^{142}$ The existence of the International Labour Organization and the inany international labor agreements it has produced, ${ }^{143}$ have further elevated labor issues beyond the nerely coincident concern of isolated nations to the nuutual concern of the entire imternational community.

Further, concern for employnent conditions transcends political and ideological categories. Although Western governments support freemarket capitalism as the nost appropriate method of ensuring workers' rights, while socialist regimes speak $\dot{\mathrm{n}} \mathrm{l}$ terms of proletarian revolution and the promise of Marxism, both sides expect to achieve an environnient in which workers may prosper. Thus, diametrically opposed political systems which suggest divergent paths of social evolution lave the same design of fortifying the working class. With support from a wide range of sources, employnent rights are einerging as bimding international legal norms.

\section{e. Nations Increasingly Recognize Nondiscrimination as Customary International Law}

"Of all the norms in international human rights law, the norm against discrimination is annong the strongest"144 and should mclude undocumented workers. ${ }^{145}$ Nondiscrimination also provides an appropriate context for applymg other hunian rights norms. Consequently, human rights constramts on employnent relationships should apply to

142. For statutory provisions, see, e.g., INTERNATIONAL LABOUR OfFICE, LegisLative SERIES 1919-83 (1984) (listing labor laws by subject and country).

For constitutional provisions, see, e.g., Ziskind, Labor Provisions in the Constitutions of Europe, 6 COMP. LAB. L. 311 (1984) (with accompanying comparative chart); Ziskind, Labor Provisions in Asian Constitutions, 6 Comp. LAB. L. 117 (1984) (same); and Ziskind, Labor Law in Latin American Constitutions, 6 CoMP. LAB. L. 1 (1984) (same).

For a general overview of comparative labor law, see, eg., Gemillscheg, Documentation, in COMPARATIVE LABOUR LAW AND INDUSTRIAL RELATIONS 25 (R. Blanpain 2d rev. ed. 1985).

143. From its first session in 1919, to its sixty-seventh in 1981, the International Labour Organization produced 156 Conventions and 165 Recommendations. INTERNATIONAL LABOUR CONVENTIONS AND RECOMMENDATIONS, 1919-1981 (ILO 1982).

144. Hoffman, The Application of International Human Rights Law in State Courts: A View from California, 18 INT'L LAW. 61, 64 (1984).

145. The Convention on Discrimination, supra note 83, defines racial discrimination as: any distinction, exclusion, restriction or preference based on race, colour, descent, or national or ethnic origin which has the purpose or effect of nullifying or inpairing the recognition, enjoyment or exercise, on an equal footing, of human rights and fundamental freedoms in the political, economic, social, cultural or any other field of public life. Id. at 216.

Paragraphs 2 and 3 of article 1 of the Convention on Discrimination, supra note 83, at 216, exempt distinctions between citizens and noncitizens from the Convention's scope, but the provisions do not appear to address distinctions between documented aliens and undocumented aliens. The restrictions appear to address matters relating to sovereignty, such as admission of aliens and procedures for naturalization. See infra text accompanying notes $169-70$. 
all, "without distinction of any kind."146 In other words, customary international law has a place for an obligatory, enforceable norm that protects the rights of undocumented workers to work, to do so at fair wages, under fair conditions, and to act collectively in the form of organized unions to facilitate their attainment and enjoyment of these rights.

\section{III}

\section{INFUSION}

This Part sets out a theory of human rights which combines domestic and international law. This theory is particularly attractive because it is historically and doctrimally sound, judicially palatable, and effective. Consequently, this Part examines four bases for "infusing" domestic law with international human rights norms: equal protection, due process, the ninth amendment, and infusion of state law.

\section{A. How and Why Infusion Works}

Although courts may not accept principles of international human rights law as directly binding, the primciples may be applied indirectly by using them to interpret and fill gaps in domestic law. This Counment refers to such a process as "infusion" rather than "indirect incorporation," because the latter term suggests that international human rights primciples exist outside the scope of doinestic law. Infusion, on the other hand, connotes a process of introspection whereby the principles of the Constitution "may be informed or illuminated by external sources of law that include emerging human rights norms."147 The infusion process therefore identifies international law principles within the body of domestic law.

Recent cases in state and federal courts have turned to international legal norms as ready standards of contemporary notions of decency with which to elucidate the meaning of domestic constitutions. In Sterling $v$. Cupp, ${ }^{148}$ the Oregon Supreme Court found that patdowns and frisks of male inmates by female officers violated the state constitution's proscription against "unnecessary rigor."149 In addition to finding abundant domestic law to support the court's conclusion, Justice Linde relied on the international law of human rights. Acknowledging worldwide concern for the dignity of prisoners, Justice Linde cited the Universal Declaration of Human Rights, the United Nations Charter, the International

146. The UDHR, supra note 60 , art. 2, para. 1, announces a list of impermissible grounds for discrimination which ends with the nearly boundless prohibition of discrimination based on "other status."

147. Christenson, supra note 82 , at 3 (emphasis added).

148. 290 Or. 611,625 P.2d 123 (1981).

149. Id. at $616-24,632,625$ P.2d at $128-32,136$. 
Covenant on Civil and Political Riglits, the European Convention for the Protection of Human Rights and Fundamental Freedoms, the American Convention on Human Rights, and the United Nations Standard Minimum Rules for the Treatment of Prisoners. ${ }^{150}$ Thus, in treating a state constitutional question, the Oregon court recognized the importance of the international instruments as contemporary expressions of all civilized governments. ${ }^{151}$

In a similar vein, the United States District Court for the District of Kansas relied on international human rights law in disapproving the extended detention of an illegally present Cuban national. ${ }^{152}$ The Tentl Circuit affirmed, notimg the propriety of considering international human riglits standards in elucidatimg the notions of fairness in the concept of due process. ${ }^{153}$

Infusion can be effective because it uses historically and doctrinally sound niethods of legal analysis and allows judges to refer to principles of international human rights law in applying the law of their jurisdiction. By formally recognizing human riglits protection as a state practice in the U.S., infusion will achieve tangible benefits for illegal aliens-by enforcing human rights-and will enhance the scope of protections under both domestic and niternational law.

Historically, United States courts have nrade extensive use of external sources to interpret doniestic law. ${ }^{154}$ This practice facilitates the development of constitutional law and conimon law. ${ }^{155}$ Infusion provides a principled basis for guidmg the evolution of constitutional lawlimiting judicial activism by relying on the text of formal legal instru-

150. Id. at 622 n.21, 625 P.2d at 131 n.21; see also U.N. CHARTER; Civil and Political Covenant, supra note 60; European Convention, supra note 60; UDHR, supra note 60; American Convention, supra note 60; U.N. Standard Minimum Rules for the Treatment of Prisoners, First U.N. Congress on the Prevention of Crime and the Treatment of Offenders, U.N. ESCOR Annex 1, at 67, U.N. Doc. A/CONF/6/1 (1955).

151. Sterling, 290 Or. at 622 \& n.21, 625 P.2d at 131 \& n.21. In another case concerning treatment of prisoners, Lareau v. Manson, 507 F. Supp. 1177 (D. Conn. 1980), aff'd in part, modified and remanded in part, 651 F.2d 96 (2d Cir. 1981), a federal court cited a series of international legal instruments to support a ruling that condemned overcrowded prison conditions as unconstitutional. The court fonnd the instruments authoritative pronouncements of basic norms of decency and fairness embodied in the Constitution's due process provisions. Id. at $1188 \mathrm{n} .9$; see also Note, supra note 65 , at 170-71 (even if standards stated in international instruments are not independently applicable in domestic courts, they are relevant to the scope of due process).

152. Fernandez v. Wilkinson, 505 F. Supp. 787, 796-98 (D. Kan. 1980), aff'd on other grounds sub nom. Rodriguez-Fernandez v. Wilkinson, 654 F.2d 1382 (10th Cir. 1981).

153. Rodriguez-Fernandez, 654 F.2d at 1388.

154. See Christenson, supra note 82 , at 35 (and cases cited throughout).

155. Labor law remains one of the few legal areas where federal common law continues to develop. Textile Workers Union v. Lincoln Mills, 353 U.S. 448, 451, 456-57 (1957). This common law is, of course, just as much the law of the land under the supremacy clause as is federal statutory or constitutional law. As emerging international hnman rights norms enter the federal common law of labor, these norms thereby become the law of the land. 
ments. ${ }^{156}$ It also avoids conflicts with courts' responsibilities under international law. Furthermore, infusion offers a way out of the judicial provincialism that occurs when courts fail to use sources of international law in defining "universal" rights. ${ }^{157}$

Courts may feel more comfortable applying their own law, as informed by the niternational law of huinan rights, than they do directly applyning international law as such. ${ }^{158}$ Infusion would assist judges in overcoming squeamishness about authoritatively interpreting and applying "external" law by instead using the external law to authoritatively interpret the law of their own jurisdiction. ${ }^{159}$ Published international huinan rights instruments identify the "autonomous international huinan rights norms [which] can be used either to fill gaps in constitutional protection or to interpret constitutional commands ...."160 In this way, judges may have the coinfort of avoiding reliance on natural law while simultaneously expanding the protection of fundamental rights.

Doctrine aside, a legal strategy that results in the protection of undocumented workers' human rights should command respect. However, at least two considerations suggest caution in arguing for infusion. First, stramed application of human rights arguments may mean that the principles advocated will enter the body of domestic law in diluted forn. ${ }^{161}$ This limitation leads to the second concern-weak arguments may result in decisions that are vulnerable to reversal on appeal. ${ }^{162}$ With these warnings $\mathrm{n} 1 \mathrm{mind}$, infusion can still positively influence the law of human rights.

Infusion allows principles drawn from hurnan rights instruments to become domestic law despite the fact that the international principles may not be obviously binding im and of themselves. ${ }^{163}$ Irrespective of the particular label attached, nations respect human rights. ${ }^{164}$ This fact nourishes the growth of human rights law by developing and strengthening the substantive content of human rights standards. ${ }^{165}$ Each time a court applies a human rights principle, the principle becomes more con-

156. Christenson, supra note 82 , at $34-36$.

157. See id. at 6.

158. Linde, Comments, Symposium on Human Rights Law in State Courts, 18 INT'L LAw. 77, $80-81$ (1984). Justice Linde sits on the Oregon Supreme Court and authored the opinion in Sterling v. Cupp, 290 Or. 611, 625 P.2d 123 (1981), discussed supra text accompanying notes 148-51.

159. See Hartman, supra note 65 , at $750-51$.

160. Christenson, supra note 82 , at 16.

161. Hartman, supra note 65 , at $750-51$.

162. This danger may be particularly acute given the current composition of the federal judiciary. Cf. Lillich, supra note 65, at 229 (suggesting time may not be ripe to argue for selfexecution of U.N. Charter norms).

163. Hoffman, supra note 144 , at 62 .

164. Lillich, supra note 65 , at 236 .

165. See Note, supra note 72 , at 215 . 
crete, which facilitates its application in the next case. As it emerges as a norm, it simultaneously enriches customary international law and domestic precedent. ${ }^{166}$ Infusion also assures that domestic law is interpreted in harmony with international law, ${ }^{167}$ and it thereby helps preserve consistency between the law of nations and the Constitution, as the supremacy clause requires. ${ }^{168}$

\section{B. Applying Infusion to Constitutional Claims}

The first step in the infusion process is to state a constitutional claim. An undocumented worker litigating employment rights must locate a constitutional subject which implicates international human rights principles. For example, failure to pay fair wages, or interference with concerted labor activity would appear to violate the FLSA and NLRA respectively. If an undocumented worker were to be denied judicial enforcement of those statutory protections, the worker could then allege a demal of equal protection-unequal administration of the law. The way would then be clear to invoke international nondiscrimination principles to illuminate the meanimg of equal protection as including undocumented workers.

The international human rights principle of nondiscrimination encompasses undocumented workers. ${ }^{169}$ When used to inform the span of equal protection, the nondiscrimination principle shows how the Constitution includes such workers within its scope. Although a nation may, for example, deny noncitizens the right to vote on the basis of sovereignty, the sovereignty rationale does not support the denial of employment rights to undocumented workers. In contrast to voting, working in the U.S. does not affect the governance of the nation, as shown by the fact that legally present ahiens have employment rights. Since legally present and undocumented aliens differ only in immigration status, not eniployment status, ${ }^{170}$ a classification based on immigration status would appear irrational in the context of employment-related rights, and would therefore fail even the most permissive equal protection test.

An alternate and complementary route to making human rights claims under the Constitution lies in the reemerging concept of substantive due process. ${ }^{171}$ Human rights instruments provide a link to the posi-

166. For a discussion of the role case law plays in customary international law, see supra text accompanying notes $67-72$.

167. See Schlüter, supra note 65 , at 157 ; Lillich, supra note 65 , at 238.

168. U.S. CONST. art. VI, cl. 2.

169. See supra text accompanying notes $144-46$.

170. See supra text accompanying notes $27-30$.

171. Notwithstanding the disrepute that the infamous decision in Lochner v. New York, 198 U.S. 45 (1905) (finding a constitutional right of freedom to contract) bestowed upon the notion of substantive due process, the concept has reemerged in the area of individual rights. See, e.g., 
tive notions of decency which inform due process analysis under a dynamic, evolving Constitution. ${ }^{172}$ Human rights principles drawn from international legal instrnments ${ }^{173}$ indicate that burdening labor-related rights would "result in a substantial departure from universal expectations of human dignity and thereby inform [a c]ourt's use of strict scrutiny."174 Scrutiny reveals the insufficiency of reasons like stemming the tide of illegal immigration, as justifications for depriving undocumented workers of sustenance. ${ }^{175}$ International human rights norms thus provide a palette of fundamental rights which domestic courts may use to complete the picture of due process.

Finally, infusion may provide an appropriate way to use the seductive yet neglected ninth amendment. ${ }^{176}$ The ninth amendment, according to John Hart Ely, signals "the existence of federal constitutional rights beyond those specifically enumerated in the Constitution . . . "177 These externally located rights may in turn be shaped in a global context by referring to international human rights law. ${ }^{178}$ The ninth amendment says there are other rights; international human rights instrnments tell where and what these rights are. ${ }^{179}$ The rights can be found in instruinents such as the International Bill of Hunian Rights, ${ }^{180}$ and these rights protect free enıployment, fair wages and working conditions, and associ-

Griswold v. Connecticut, 381 U.S. 479, 485 (1965) (right of privacy protects use of contraceptives); Roe v. Wade, 410 U.S. 113, 152-56 (1973) (right to abortion).

172. See Hartman, supra note 65 , at 750-51; Note, supra note 65 , at 167-70.

173. For a discussion, in the context of customary international law, of the fundamental nature of employment rights, see supra text accompanying notes 129-43.

174. Christenson, supra note 82 , at 30 .

175. Scrutiny of burdens on employment rights is discussed supra text accompanying notes 25 43.

176. U.S. CONST. amend. IX provides: "The enumeration in the Constitution, of certain rights, shall not be construed to deny or disparage others retained by the people." The ninth amendment has rarely been relied upon by courts or commentators as a potent guarantor of individual rights, in spite of its expansive wording. See Moore, The Ninth Amendment-Its Origins and Meaning, 7 NEW ENG. L. REV. 215, 217 (1972). Justice Goldberg's use of the ninth amendment in Griswold $v$. Connecticut, 381 U.S. 479, 485-86 (1965) (Goldberg, J., concurring), for example, was not well received. See, e.g., Griswold, 381 U.S. at 518-20 (Black, J., dissenting) (disapproving broad reading); Kelley, The Uncertain Renaissance of the Ninth Amendment, 33 U. CHI. L. REV. 814 (1966) (same).

177. J. ElY, DEMOCRACY AND DISTRUST: A THEORY OF JUdICIAL REVIEW 38 (1980); sce also Brest, The Fundamental Rights Controversy: The Essential Contradictions of Normative Constitutional Scholarship, 90 YALE L.J. 1063, 1088 (1981) (quoting Ely with approval); Moore, supra note 176, at 246-56 (Constitution's framers intended ninth amendment to protect natural rights).

178. See Christenson, supra note 82 , at 13 .

179. See Lareau v. Manson, 507 F. Supp. 1177, 1187-88 \& n.9 (D. Conn. 1980), aff'd in part, modified and remanded in part, 651 F.2d 96 (2d Cir. 1981) (affirming district court applieation of international law principles while modifying trial court's remedy).

180. See supra note 126; Burke, Coliver, De la Vega \& Rosenbaum, Application of International Human Rights Law in State and Federal Courts, 18 TEx. INT'L L.J. 291, 293 (1983). For a more comprehensive list of pertinent human rights instruments, see supra text accompanying notes 129 36. 
ational liberties. ${ }^{181}$ Tlius, an undocumented worker could point to Article 23 of the Universal Declaration of Human Riglits as mdicating his or her riglit to "just and favourable conditions of work," 182 which thougl not enumerated in the Constitution miglit still be a right retained by the people. ${ }^{183}$

Infusion may take on further strategic advantages when applied to state law. State law infusion parallels that of federal law except that international human rights principles would arise as explications of state rather than federal constitutional provisions. A threshold requirement is satisfied where states recognize international law as part of their law. ${ }^{184}$ Once $\mathrm{m}$ the realm of state law, a state court can base its decision on independent and adequate state grounds, thereby insulatimg itself from federal court reversal. ${ }^{185}$ Such insulation may prove useful in view of the corresponding principle that states may confer broader rights than the federal government, even under identical constitutional language. ${ }^{186}$

\section{IV}

\section{Policy Considerations and Posture}

The probleins which undocumented workers face cannot be addressed or resolved im a legal vacuum. The very subject of undocuinented workers implicates inoral and political value judgments. ${ }^{187}$ This Part will assert that protecting the employment rights of undocumented workers does not conflict with other policy concerns, and that ethical concerns compel such protection.

\section{A. Politics}

Protecting the employment rights of undocumented workers fur-

181. See supra text accompanying notes $129-37$

182. UDHR, supra note 60 , art. 23.

183. U.S. CONST. amend. IX.

184. See, e.g., Sterling v. Cupp, 290 Or. 611, 622 \& n.21, 625 P.2d 123, 131 \& n.21 (1981) (Oregon law embodies international norm against unreasonable searches); Respublica v. De Longchamps, 1 Dall. 111, 114 (Pa. 1784) (Pennsylvania law includes the law of nations); Hoffman, supra note 144, at 65 (California recognizes international human rights law as California law).

185. See Michigan v. Long, 463 U.S. 1032, 1038-44 (1983). To be insulated from federal court reversal, a state court must rely on state law precedent interpreting the state constitution, and indicate by a "plain statement" that any federal precedent which the state court cites in support of its conclusions is merely illustrative of similar principles. Id.

186. Id. at 1044 n.10; see also Brennan, State Constitutions and the Protection of Individual Rights, 90 HARV. L. REV. 489 (1977).

187. In addition, practical considerations regarding jurisdiction and judicial abstention under the sovereign immunity, act-of-state, and political question doctrines may stand between an aggrieved undocumented worker and relief in United States courts. These potential obstacles are not, however, insurmountable. See Note, supra note 72, at 222-27; Comment, Enforcing the Customary International Law of Human Rights in Federal Court, 74 CALIF. L. REv. 127 (1986). But these considerations are beyond the scope of this Comment. 
thers both labor and immigration policy. The putative conflict is that protecting illegal ahen workers will undermine immigration policy by encouraging illegal immigration, ${ }^{188}$ but two practical considerations reveal this argument's illusory nature. In the first place, immigration law proscribes only knowimg employment of illegal aliens. ${ }^{189}$ Enforcing labor law protections does not specifically imply the transgression of immigration laws. Furthermore, immigration laws should not be used to construe unrelated statutes which govern the rights of workers. ${ }^{190}$ In other words, the definitions of "employee" which determine the coverage of laws such as the Fair Labor Standards Act, ${ }^{191}$ and the National Labor Relations Act, ${ }^{192}$ should not be affected by immigration laws.

Second, declining to enforce employment standards for illegal aliens simply does not reduce illegal immigration. Most undocumented workers come to this country out of "the basic human desire to work to be able to feed themselves and their families." 193 Such persons are unlikely to base their immigration decisions on legal niceties, especially when whatever conditions this nation offers are "vastly superior to what is available in their home countries."194 Quite simply, their need for basic sustenance outweighs any fears they have of deportation or exploitation. Thus, illegal immigration continues irrespective of the scope of labor rights afforded to undocumented workers. ${ }^{195}$

188. For additional discussion of the relationship between labor and immigration laws, see supra text accompanying notes 10, 25-30.

189. Simpson-Rodino Act, supra note 2, tit. I, sec. 101, § 274A(a)(1)(B). The Simpson-Rodino Act excuses employers from sanctions for hiring undocumented aliens if they have made a "good faith" effort to verify the immigration status of their employees. Id., tit. I, sec. 101, $\S 274 \mathrm{~A}(\mathrm{a})(3)$.

Simpson-Rodino repealed the Texas Proviso, 8 U.S.C. $\S 1324(a)(3)$, discussed supra text accompanying note 30 , which had excepted employment and its usual and natural incidents from proscription. See Local 512, Warehouse \& Office Workers' Union v. NLRB, 795 F.2d 705, 719 (9th Cir. 1986); Hull, supra note 2, at 425 n.70.

The California Labor Code makes it illegal to employ undocumented aliens only if such employment would adversely affect lawful resident workers. CAL. LAB. CODE $§ 2805$ (a) (West Supp. 1985); see also Kutchins \& Tweedy, supra note 3, at 348.

190. See Note, supra note 9 , at 865 n. 82 . Conversely, immigration law issues should not be decided in the context of labor law (NLRB) proceedings. See Local 512, 795 F.2d at 719-22 (criticizing NLRB for ruling on immigration status).

191. 29 U.S.C. $\$ \S 201-219$ (1982).

192. 29 U.S.C. $\S \S 151-187$ (1982).

193. Ortega, supra note 10 , at 251.

194. Developments, supra note 2, at 1437 (footnote omitted).

195. See supra note 31 and accompanying text. But cf. Note, supra note 51, at 687 ("Including illegal aliens under the NLRA could reduce employer incentive to hire them and will reduce the aliens' incentive to enter the country illegally, as jobs will not be as readily available ...."); Shenon, 'Startling' Surge Is Reported In Illegal Aliens From Mexico, N.Y. Times, Feb. 21, 1986, § 1, at 1, col. 1 (nat'l ed.) (Immigration and Naturalization Service Commissioner supports sanctions against employers as deterrent to illegal immigration). 


\section{B. Ethics}

Given the inevitability of continued illegal immigration, ethical considerations call for broad einployinent protections for undocumented workers. In view of the benefits that undocumented workers provide to the United States economy ${ }^{196}$ and the United States' image as a protector of hunian rights, ${ }^{197}$ the nation cannot avoid hypocrisy as long as it denies illegal alien workers their employnient rights.

\section{Economic Benefits}

Contrary to assertions that illegal aliens burden the United States economy by taking jobs that would otherwise be filled by citizens or resident ahens, it appears that undocuinented workers actually stimulate the nation's economy. ${ }^{198}$ The jobs that illegal aliens take are generally ones which United States laborers would refuse. ${ }^{199}$ To the extent they do coinpete directly with U.S. workers, any job losses or wage reductions suffered by the domestic laborers, although " 'more visible than the economic gains,' are outweighed by the overall increase in national output, which 'increases the per capita incolne of the native-born U.S. population." "200 In addition, the cheap labor pool which illegal aliens provide increases productivity by helping Americans perform their work more efficiently. ${ }^{201}$ Finally, undocumented workers increase the national fisc by paying taxes but not consuming their share of social services due to fear of detection. ${ }^{202}$ Thus, illegal aliens who work in the United States should not be deprived of their huinan rights on the faulty prenise that they drain resources from the American economy.

\section{United States Human Rights Image}

Because the United States champions human rights, ${ }^{203}$ it should

196. See, eg., Pear, Reagan's Advisers Say Bill On Aliens Can Hurt Economy, N.Y. Times, Jan. 23, 1986, $\S 1$, at A1, col. 6 (nat'l ed.) (aliens, legal and illegal, "increased total employment . . . in this country as well as the per-capita income of the native-born population.").

197. See, e.g., Note, supra note 72, at 232 ("[I]t is clear that United States commitment to international human rights has been steadfast.").

198. Developments, supra note 2, at 1442-43.

199. Id. at 1442.

200. Pear, supra note 196, at 12, col. 5 (quoting President Ronald Reagan's Council of Economic Advisers' draft report concerning employment of illegal aliens, Jan. 22, 1986).

201. Id. Low-skilled foreign workers increase productivity by doing mundane tasks which free others to do their work more efficiently. Id. at 12, cols. 5-6.

202. Developments, supra note 2, at 1442-43.

203. See Text of the Reagan Message to Congress on Foreign Policy, N.Y. Times, Mar. 15, 1986, $\S 1$, at 4, col. 1 (nat'l ed.); see also Note, supra note 72, at 231-32 \& nn.142-45 (referring to cases where courts took judicial notice of "Executive pronouncements on [international] human rights issues."). 
confirm that image with substantive policy. ${ }^{204}$ The moral force of the U.S. as a human rights advocate would be severely undermined if the nation chastised others for acts that the U.S. condoned domestically. In order for the United States to effectively influence other nations to protect hunıan rights, it should not leave itself open to human rights criticism. Thus, to nuamtain its stature in a legal schenie that transcends national boundaries, the United States should enforce the human rights of undocumented workers within its boundaries.

\section{CONCLUSION}

Undocumented workers in the United States endure systematic deprivations of their eniployment-related hunian rights. Doniestic and international sources of legal norms, effectively advocated, offer protection to these illegal ahens. In the donestic sphere, constitutional arguments suggest that undocumented workers merit judicial solicitude, and that employment-related rights are basic, such that their demal inıplicates due process concerns. Combining the preceding theories, it follows that the strength of illegal ahens' claims to equal protection increases with the fundamentality of the right at issue. Since working rights are fundamental, undocumented workers should not be denied those rights without adequate justification. The constitutional arguments in turn bolster statutory arguments that the Fair Labor Standards Act, the National Labor Relations Act, and other pertinent legislation affirmatively cover undocumented workers.

In the context of international law, declarations of international bodies, case law, and the writings of scholars counsel liberal construction of hunian rights nistrunients to include the rights of undocuinented workers. The hunian rights principles drawn from these instruments offer protection either as treaty law or custoniary international law, both of which are the law of the land under the supremacy clause. As treaty law, those provisions of the U.N. Charter that support undocuniented workers' rights should, by virtue of the parties' intent, the judicial inanageability of the standards they prescribe, and the adverse consequences of a contrary decision, be deemed self-executing and therefore judicially enforceable by aggrieved individuals. As international custom, employment rights and nondiscrimination have garnered sufficiently uniform recognition among civilized nations so as to be called upon as binding international law and to be invoked in domestic fora to protect undocumented workers.

Though doniestic and international law theories both suffer short-

204. Fernandez v. Wilkinson, 505 F. Supp. 787, 799 (D. Kan. 1980), aff'd sub nom. RodriguezFernandez v. Wilkinson, 654 F.2d 1382 (10th Cir. 1981). 
comings if invoked independently, they appear encouragingly acceptable when combined. The process of infusing the many open-ended provisions of domestic law with positive meaning derived from the international law of human rights recommends itself as historically and technically sound, judicially palatable, and effective in gaining tangible benefits for undocumented workers and expanding the content of both constitutional law and customary international law. Accordingly, undocumented workers could make strong constitutional claims for infusing equal protection with a broad norm of nondiscrimination, due process with positive standards of fundamental rights that include workrelated rights, and the ninth amendment with textually anchored "unenumerated rights" that encompass nondiscrimination and workers' rights. These theories could also be used to infuse state law, protecting against federal court reversals.

Regardless of the theory applied, policy considerations support protecting the rights of undocumented workers. Political considerations suggest the propriety of bringing domestic judicial policy into harmony with international obligations. Finally, in view of the economic benefits that undocumented workers offer the U.S. economy, and our nation's positive image as a human rights leader, failing to guarantee the rights of undocumented workers is difficult to justify.

Neil A. Friedman*

* A.B. 1983, University of California, Berkeley; third-year student, Boalt Hall School of Law, University of California, Berkeley. 
